organize both LSS and APSA Legislative Politics panels for the 1989 APSA meeting in Atlanta.

The Legislative Studies Section continues in 1988 to be led by L. Sandy Maisel of Colby College while Lawrence D. Longley of Lawrence University serves as Secretary-Treasurer and Editor of the LSS Newsletter. Melissa P. Collie of the University of Texas, Catherine E. Rudder of the American Political Science Association, and Glenn R. Parker of Florida State University, serve on the Section's Executive Board.

During 1987-88, the LSS provided extensive coverage of professional activities and information of interest to legislative scholars in issues of the LSS Newsletter which ran to a total of 300 pages for the year. The two regular issues of November and May contained a wealth of information concerning recent and forthcoming professional meetings, LSS activities, professional notes, book reviews, and mini professional articles in the "Extension of Remarks" section edited by Larry Dodd of the University of Colorado. This Newsletter section in 1987-88 included symposia of original professional research and scholarly analysis on "Congress and Public Policy" and "The United States Congress in Comparative Perspective."

The two regular Newsletter issues were supplemented by the 1988 LSS Membership Directory and Research Register. This guide was drawn from the LSS Data Base, which is regularly updated and revised to incorporate latest information supplied by LSS members concerning current addresses and legislative research interests. The 1988 Directory reported addresses and research interests as of April I, 1988, for a record 692 members of the Legislative Studies Section.

In 1987, the Legislative Studies Section launched a new LSS Book Series on Legislative Research to be published every two years by the University of Tennessee Press. Each volume in the series will contain 8 to 12 original studies of emerging or persistent questions in the study of legislative politics and behavior. Additional information concerning the LSS Book Series on Legislative Research is available from the
Series editor, Glenn R. Parker, Department of Political Science, The Florida State University, Tallahassee, FL 32306.

\section{Legislative Studies Section Gives CQ Press Award; Announces Prize Committee for 1989}

At a special awards ceremony held on September 1 in conjunction with the American Political Studies Association Annual Meeting in Washington, DC, the Legislative Studies Section of the APSA conferred the $1988 \mathrm{CQ}$ Press Award, and announced the $\mathrm{CQ}$ prize committee for 1989.

The CQ Press Award honors the outstanding paper in legislative politics presented at the year's preceding APSA Annual Meeting. The 1988 winners were John R. Hibbing of the University of Nebraska and John Alford of Rice University for their 1987 APSA paper "Responsiveness in the Senate." The prize was decided upon by an LSS Committee chaired by David Brady of Stanford University and including Keith E. Hamm of Texas A\&M University.

In their award winning paper, Hibbing and Alford argued that the central intended dynamic of the bicameral arrangement of the U.S. Congress is the interaction of an electorally sensitive House of Representatives with an electorally insular and more reflective Senate. Concerned that the lower house would prove to be "changeable, and susceptible to excess," the founders crafted an electoral arrangement that would shield the upper house as a necessary "defense to the people against their own temporary errors and delusions" (Federalist 63). Observers of the contemporary Senate see little evidence that the body is fulfilling this restraining role. The methods by which the founders sought to establish the distinctive nature of the two chambers were electoral, and the historical performance of those mech- 
anisms can go a long way toward placing the current Senate in perspective. To this end Hibbing and Alford examine the two chambers' patterns of switches in partisan control, levels of turnover, swing ratios (seat change over vote change), and tipping points (vote change required to reverse partisan control). In each case the evidence points to electoral convergence between the two chambers, and there is even some suggestion of a reversal of their constitutionally intended roles. They close with a consideration of the causes of these historic shifts, and an assessment of the operational and policy consequences that flow from them.

The CQ Press Award is given by the Legislative Studies Section each year to honor outstanding scholarship as reflected in the papers presented at each year's national meeting. Consideration for this prize is not limited to papers presented at panels organized by the Legislative Studies Section or at APSA Legislative Politics panels, but honors the best papers on legislative politics presented at any panel at the APSA meeting.

The 1989 CQ Press Award Committee is chaired by Melissa P. Collie of the University of Texas. Other members are Alan Abramovitz of Emory University and Wayne L. Francis of the University of Florida. The 1989 prize will be announced and conferred at the 1989 Awards Ceremony of the Legislative Studies Section held during and in conjunction with the Annual Meeting of the American Political Science Association in Atlanta. It will honor the best paper in legislative politics delivered at the 1988 APSA Annual Meeting.

\section{Richard F. Fenno, Jr. Prize for 1988 Announced; Award Committee for 1989 Set}

The Legislative Studies Section of the American Political Science Association an-

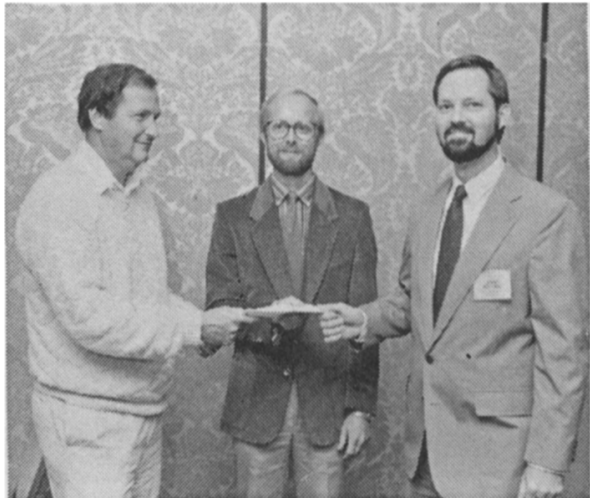

David Brady presents Legislative Studies Section's CQ Press Award to John R. Hibbing and John Alford.

nounced the 1988 winner of the Richard $F$. Fenno, Jr. Prize at the LSS Awards Ceremony held in Washington at the APSA Annual Meeting. The Fenno Prize honors the outstanding book published during the preceding year in legislative studies, including American, non-American, crossnational, and sub-national works.

The 1988 Fenno Prize was conferred jointly upon Bruce Cain, John Ferejohn, and Morris Fiorina for their book The Personal Vote: Constituency Service and Electoral Independence, published in 1987 by Harvard University Press. Other members of the Fenno Committee were Diana Evans, Trinity College, and Stephen Frantzich, the U.S. Naval Academy.

Speaking on behalf of the Fenno Prize Committee, Diana Evans reported:

The Personal Vote: Constituency Service and Electoral independence by Bruce Cain, John Ferejohn, and Morris Fiorina, is a carefully crafted study of the role played by constituency service in the electoral fortunes of members of the United States House of Representatives and the British House of Commons. It resolved a major paradox in the literature: that district service has increased in volume and perceived importance to members over the years, but seems not to have had large effects on their electoral fates. The authors convincingly demonstrate that we have been looking in the wrong place: the effects are substantial, but indirect. Politicians do indeed know what they are doing. Cain, Ferejohn and 